\title{
BIG FIVE PERSONALITY TRAITS, DEMOGRAPHY AND OVERCONFIDENCE
}

\author{
Latifah Putranti \\ Fakultas Bisnis, Universitas PGRI Yogyakarta, Indonesia \\ Email: Latifah@upy.ac.id
}

\begin{abstract}
This study aims to determine the factors that influence overconfidence in student investors in Yogyakarta. This study explores the relationship between demographic factors (sex, age, education) and big five personality traits (agreeableness, concientiousness, extraversion, neuroticism, openness) with overconfidence. Primary data collected from student investors through questionnaires. The statistical method used is chi-square to determine the relationship between demographic factors and overconfidence. Regression method to determine the relationship between personality types with overconfidence. Analysis using SPSS for Windows 20 on 100 sample sizes. The results of the regression analysis showed that there was an influence between concientiousness, extroversion and openness personality type variables on overconfidence. Agreeableness and neuroticism have no effect on overconfidence. The study also found an influence between demographic factors (sex, age, education) and overconfidence.
\end{abstract}

Key Words: Behavioral Finance, Overconfidence, Big Five Personality Traits, Demographics Variables.

\section{PENDAHULUAN}

Minat mahasiswa di Daerah Istimewa Yogyakarta (DIY) untuk menginvestasikan uangnya di pasar modal cukup tinggi. Berdasarkan data PT Kustodian Sentral Efek Indonesia (KSEI) hingga tanggal 31 Oktober 2013 tercatat ada sebanyak 4.751 investor yang berdomisili di DIY dan 20 persennya dari kalangan mahasiswa (Muhammad, 2013). Secara rasional, investor akan memilih saham-saham yang menguntungkan dengan mempertimbangkan tingkat return dan resiko dari saham tersebut. Fluktuasi harga dan peristiwa tertentu membuat beberapa investor melakukan transaksi yang berbeda dengan investor lainnya dan mendapatkan keuntungan yang dinamakan abnormal return. Behavioral finance merupakan cara untuk menjelaskan keberadaan abnormal return. Barberis dan Thaler (2003) berpendapat bahwa dalam behavioral finance, perilaku investor yang irasional dikarenakan keterbatasan dalam memproses informasi.

Studi tentang investor tidak rasional di pasar modal, bermula dari penelitian DeBondt dan Thaler (1985) menemukan bahwa di dalam kondisi tertentu, perilaku investor yang tidak rasional benar-benar ada. Mereka menunjukkan bahwa orang cenderung memberikan bobot yang berlebihan pada informasi laba terakhir dan mengabaikan informasi laba sebelumnya sehingga menciptakan kondisi pasar yang under dan overreacted. Pompian (2006) berpendapat bahwa ketika orang dihadapkan dengan ketidakpastian, mereka cenderung mengambil keputusan yang 
overconfidence sehingga menimbulkan kesalahan yang lebih banyak dibandingkan ketika mereka berperilaku rasional. Terjadinya bias overconfidence yang menyebabkan beberapa kesalahan fatal, membuat banyak peneliti mencari tahu faktor-faktor yang mempengaruhinya. Kufepaksi (2010) faktor gender mempengaruhi dimana investor pria cenderung overconfidence di bandingkan dengan investor wanita. Penelitian yang dilakukan Bashir et al (2013) pada mahasiswa sebagai investor di Pakistan, menemukan bahwa faktor demografi yaitu usia dan pendidikan berhubungan signifikan terhadap bias overconfidence.

Secara khusus, kebanyakan studi di bidang keuangan perilaku hanya bergantung pada faktor-faktor eksternal yang mendasari investor dalam pengambilan keputusan (Graham et al, 2009). Tidak banyak yang mengamati perbedaan di tingkat individu seperti sifat-sifat psikologis yang dapat membantu untuk lebih menjelaskan mekanisme yang mendasari berbagai bias perilaku (Ferguson et al, 2011). Dengan demikian, menurut pelitian Lin (2011) tipe kepribadian big five memainkan peranan penting dalam menentukan bias perilaku overconfidence yang terjadi pada investor. Lima sifat kepribadian tersebut adalah sifat extraversion, agreeableness, conscientiousness, neuroticism dan openness. Bashir et al (2013) melakukan penelitian untuk menganalisis hubungan antara ciri-ciri kepribadian dengan bias overconfidence yang terjadi pada mahasiswa dan pegawai dengan hasil penelitian menunjukkan bahwa semua ciri-ciri kepribadian The Big Five Personality yaitu (agreeableness, constientiousness, extraversion, neuroticism dan openness to experience) berkorelasi (mempunyai hubungan) dengan overconfidence.

\section{KAJIAN PUSTAKA Overconfidence}

Overconfidence merupakan karakteristik yang paling umum ditemui dalam diri manusia yang menyebabkan orang overestimate terhadap pengetahuan yang dimiliki, dan underestimate terhadap risiko serta melebih-lebihkan kemampuan mereka dalam hal melakukan kontrol atas apa yang terjadi. Overconfidence akan mempengaruhi investor dalam mengambil risiko tinggi untuk memperoleh keuntungan, sementara investor yang rasional berusaha untuk memaksimalkan keuntungan dengan cara memperkecil jumlah dari risiko yang diambil (Nofsinger, 2005).

Tipe Kepribadian Big Five Theory

MC Crae \& Costa (1997) kepribadian Big Five terdiri dari lima dimensi yaitu :

\section{Tabel 1}

Tipe Kepribadian Big Five

\begin{tabular}{ll}
\hline \multicolumn{1}{c}{ Sifat } & \multicolumn{1}{c}{ Karakteristik dengan skor tinggi } \\
Agreeableness (A) & $\begin{array}{l}\text { Berhati lembut, baik, suka menolong, dapat dipercaya, } \\
\text { mudah memaafkan, mudah untuk dimanfaatkan, terus } \\
\text { terang. }\end{array}$ \\
Conscientiousness (C) & $\begin{array}{l}\text { Teratur, dapat dipercaya, pekerja keras, disiplin, tepat } \\
\text { waktu, teliti, rapi, ambisius, tekun. }\end{array}$ \\
\hline
\end{tabular}

Bisman (Bisnis dan Manajemen): The Journal Of Business and Management 


\begin{tabular}{ll}
\hline Extraversion (E) & $\begin{array}{l}\text { Mudah bergaul, aktif, talkative, person-oriented, optimis, } \\
\text { menyenangkan, kasih sayang, bersahabat. }\end{array}$ \\
Neuroticism (N) & $\begin{array}{l}\text { Kuatir, cemas, emosional, merasa tidak nyaman, kurang } \\
\text { penyesuaian, kesedihan yang tak beralasan }\end{array}$ \\
Openness $(\mathbf{O})$ & $\begin{array}{l}\text { Rasa ingin tahu tinggi, ketertarikan luas, kreatif, original, } \\
\text { imajinatif, tidak ketinggalan jaman. }\end{array}$ \\
\hline
\end{tabular}

\section{KERANGKA BERFIKIR}

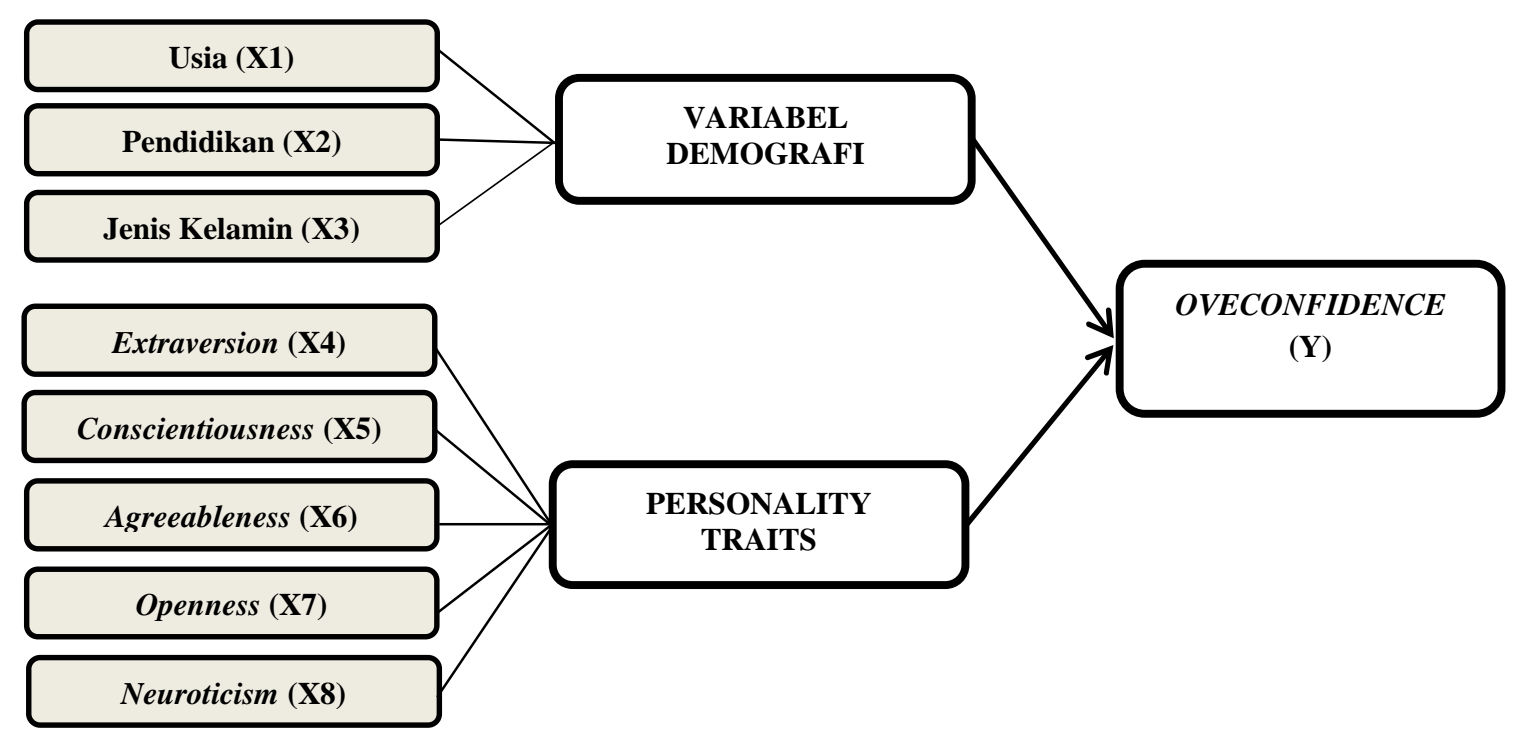

\section{PENGEMBANGAN HIPOTESIS}

1. Hubungan jenis kelamin dengan overconfidence

Felton et al (2003) pria memiliki keberanian yang lebih tinggi mengambil risiko investasi dibandingkan dengan wanita karena pria lebih optimistik ketika menghadapi peristiwa-peristiwa dimasa yang akan datang. Geffert dan Christensen (1998) siswa perempuan sering meremehkan diri mereka sendiri, sementara siswa laki-laki cenderungan melebih-lebihkan kemampuan mereka sendiri. Penelitian Mishra (2015), Bashir et al (2013), Rekik \& Boujelbene (2013), Tekce (2011), Lin (2011), Kufepaksi (2010) dan Graham et al (2009) menunjukkan bahwa overconfidence laki-laki lebih tinggi dari pada wanita

H1 : Jenis kelamin berpengaruh positif terhadap overconfidence.

2. Hubungan usia dengan overconfidence

Menkhoff et al (2006) tingkat overconfidence meningkat seiring dengan pengalaman investor yang bertambah usia. Korniotis \& Kumar (2011) investor lebih tua lebih overconfidence dibandingkan dengan investor muda karena mempunyai pengalaman yang kurang. Hasil penelitian Onsomu (2015), Bashir et al (2013), Rekik \& Boujelbene (2013), Tekce (2011) dan Lin (2011) menunjukkan bahwa variabel demografi yaitu usia berpengaruh positif terhadap overconfidence.

H2 : Usia berpengaruh positif terhadap overconfidence.

Bisman (Bisnis dan Manajemen): The Journal Of Business and Management 


\section{Hubungan pendidikan dengan overconfidence}

Tingkat pendidikan yang lebih tinggi menyiratkan bahwa orang memiliki pemahaman yang lebih baik dari masalah keuangan pribadi mereka, sehingga mereka akan lebih mampu untuk membuat keputusan keuangan dan memiliki kemampuan lebih untuk merencanakan masa depan mereka. Sembel \& Irwan (2011) menyatakan bahwa mahasiswa dengan kualifikasi pendidikan yang tinggi menunjukkan tingkat overconfidence yang tinggi. Hasil penelitian Bhandari \& Dhaves (2006), Graham (2009), Jamshidinavid et al (2012), Bashir et al (2013), Mishra \& Mary (2015) dan Thomas dan Shinil (2015) menunjukkan bahwa variabel demografi berpengaruh positif terhadap overconfidence pada investor.

H3 : Pendidikan berpengaruh positif terhadap overconfidence.

4. Hubungan agreeableness dengan overconfidence

Robbins et al (2008) Orang yang sangat menyenangkan, hangat, koperatif dan dapat dipercaya mempunyai tingkat kepercayaan diri. Zaidi \& Tauni (2012) individu yang ramah, baik, murah hati, membantu, yang suka berkompromi dan bekerja sama dengan orang lain memiliki tingkat overconfidence terhadap keputusan keungannya.

Hipotesis 4 : Agreeableness berpengaruh positif terhadap overconfidence.

5. Hubungan conscientiousness dengan overconfidence

Schaefer et al (2004) investor dengan sifat ini akan serius, target seeker dan unggul, percaya bahwa performa mereka sendiri yang lebih baik dari investor lain dalam investasi. Robbins et al (2008) concientiousness merupakan individu yang gigih, terorganisir dan dapat diandalkan. Dapat dicirikan sebagai orang yang bisa diandalkan, berorientasi pada prestasi, dan tertib (Rothman \& Contzer, 2003). Jamhidinavid (2012), Zaidi (2012) \& Bashir (2013) pada penelitiannya menyimpulkan bahwa conscientiousness mempunyai tingkat overconfidence yang tinggi.

Hipotesis 5 : Conscientiousness berpengaruh positif terhadap overconfidence.

6. Hubungan extraversion dengan overconfidence

Robbins (2001) extraversion cenderung senang untuk bergaul dengan sesama disekitarnya, sehingga memiliki relasi yang cukup luas. Penelitian Peterson (2011) orang dengan kepribadian extraversion akan cenderung lebih suka untuk mengambil resiko. Extraversion berhubungan dengan overconfidence (Pallier et al, 2002), extraversion berhubungan dengan narsisme (Paulhus \& Williams, 2002) dan narsisme berkorelasi dengan overconfidence. Hasil penelitian Amiri et al (2013), Bashir et al, Jamshidinavid (2012), Lin (2011), Schaefer et al (2004) tipe kepribadian investor extroversi (extroversion) menunjukkan tingkat overconfidence yang tinggi.

Hipotesis 6 : Extroversion berpengaruh positif terhadap overconfidence. 


\section{Hubungan neuroticism dengan overconfidence}

Robbins et al (2008) neuroticism mengacu pada stabilitas emosi dan kemampuan seseorang untuk menahan stres. Mereka dengan skor negatif yang tinggi maka cenderung gugup, cemas, depresi, dan tidak aman. Neurotisisme berhubungan negatif dengan overconfidence (Williams, 1992), dan depresi berkaitan dengan underconfidence (Stone et al., 2001). Lin (2011) menurut penelitiannya tipe kepribadian neurotisme (neuroticism) pada investor di Taiwan terjadi korelasi negatif dengan bias overconfidence. Selain itu menurut penelitian yang dilakukan Zaidi (2012) tipe kepribadian neuroticism pada investor di Pakistan juga berhubungan negatif dengan overconfidence.

\section{Hipotesis 7 : Neuroticism berpengaruh positif terhadap overconfidence.}

8. Hubungan Openness dengan overconfidence

Robbins et al (2008) seseorang yang tertarik terhadap hal-hal baru. Schaefer et al (2004) tipe kepribadian openness mempunyai rasa ingin tahu, kasih sayang berubah-ubah dan keingintahuan intelektual, sehingga mereka sering membeli dan menjual saham karena overconfidence. Barber \& Odean (1999) menemukan, investor dengan sifat openness merupakan individu yang tertarik untuk hal-hal baru dan pengalaman baru, berorientasi pada tindakan, dan ingin tahu tentang ide orang lain membeli dan menjual saham mereka karena kepercayaan diri yang tinggi. Lin (2011), (Jamshidinavid, 2012), Bashir et al (2013) \& Amiri (2013) tipe kepribadian openness pada investor berpengaruh positif terhadap overconfidence.

Hipotesis 8 : Openness berpengaruh positif terhadap overconfidence.

\section{POPULASI DAN SAMPEL PENELITIAN}

Penelitian ini mengambil populasi yang merupakan investor yang merupakan mahasiswa di Yogyakarta. Teknik pengambilan sampel pada penelitian ini adalah non probability sampling dimana tidak semua individu pada populasi memiliki kesempatan menjadi anggota sampel, hanya individu-individu tertentu dalam populasi yang mendapatkan kesempatan menjadi anggota sampel (Sugiama, 2012). Populasi dalam penelitian ini adalah mahasiswa di kota Yogyakarta yang melakukan perdagangan saham terutama yang tergabung dalam Kelompok Studi Pasar Modal (KSPM). Dikarenakan jumlah populasi untuk penelitian ini sulit untuk diketahui jumlah pastinya, maka pengambilan sampel dilakukan dengan menggunakan teknik convenience sampling. Dari populasi yang jumlahnya tidak pasti, maka untuk menentukan jumlah sampel dalam penelitian ini maka digunakan rumus (Lemeshow \& David, 1997) dimana ukuran sampel yang digunakan dalam penelitian ini sebanyak 100 orang mahasiswa yang pernah melakukan trading yang tergabung dalam KSPM maupun bukan. 


\section{METODE ANALISIS DATA}

\section{Analisis Chi-Square dan Analisis Regresi}

Analisis bivariat untuk mengetahui hubungan antar variabel dependent overconfidence dengan variabel independent faktor demografi yang terdiri dari jenis kelamin, usia dan pendidikan. Analisa data yang digunakan adalah Korelasi Spearman atau Chi Square. Korelasi Spearman berfungsi untuk menentukan besarnya hubungan dua variabel yang berskala ordinal. Uji Chi Square berfungsi untuk mengetahui ada tidaknya hubungan antara variabel dan data harus berskala nominal. Pengujian menggunakan tingkat signifikansi 0,05 dengan menggunakan program SPSS 20 for windows. Untuk menguji hubungan tipe kepribadian dengan overconfidence maka menggunakan menggunakan fasilitas analisis regresi. Output yang dibutuhkan dari pengujian tersebut adalah tabel Coefficients dan tabel Anova.

\section{HASIL DAN PEMBAHASAN}

1. Profil Responden

\begin{tabular}{|c|c|c|}
\hline \multicolumn{3}{|c|}{$\begin{array}{c}\text { TABEL } 2 \\
\text { PROFIL RESPONDEN }\end{array}$} \\
\hline Variabel & Frekuensi & Presentase \\
\hline \multicolumn{3}{|c|}{ Jenis Kelamin } \\
\hline Laki-laki & 45 & $45 \%$ \\
\hline Perempuan & 55 & $55 \%$ \\
\hline \multicolumn{3}{|l|}{ Usia } \\
\hline$\leq \mathbf{3 0}$ & 82 & $82 \%$ \\
\hline $31-40$ & 14 & $14 \%$ \\
\hline $41-50$ & 4 & $4 \%$ \\
\hline \multicolumn{3}{|l|}{ Pendidikan } \\
\hline S1 & 54 & $54 \%$ \\
\hline $\mathbf{S 2}$ & 40 & $40 \%$ \\
\hline S3 & 6 & $\%$ \\
\hline
\end{tabular}

\section{Uji Validitas}

Uji validitas dilakukan sebelum kuisioner disebar kepada responden yang sesungguhnya dengan melakukan uji pilot yang disebar kepada 30 responden yang memenuhi prasyarat. 


\begin{tabular}{|c|c|c|c|c|}
\hline \multicolumn{5}{|c|}{ Tabel 3} \\
\hline \multicolumn{5}{|c|}{ Item Valid dan Gugur Tipe Kepribadian Big Five } \\
\hline \multirow[t]{2}{*}{ No } & \multirow[t]{2}{*}{ Aspek } & \multicolumn{2}{|l|}{ Item } & \multirow[t]{2}{*}{ Jumlah } \\
\hline & & Valid & Gugur & \\
\hline 1 & Agreeableness & $2,7,12,17,22,27,32,37,42$ & - & 9 \\
\hline 2 & Conscientiousness & $3,8,13,18,23,28,33,38,43$ & - & 9 \\
\hline 3 & Extraversion & $1,6,11,16,21,26,31,36$ & - & 8 \\
\hline 4 & Neuroticism & $4,9,14,19,29,34,39$ & 24 & 8 \\
\hline 5 & Openness & $5,10,15,20,25,30,35,40$ & 41 & 10 \\
\hline & TOTAL & 42 & 2 & 44 \\
\hline 6 & Overconfidence & $1,2,3,4,5$ & - & 5 \\
\hline & TOTAL & 5 & 0 & 5 \\
\hline
\end{tabular}

Item pertanyaan tipe kepribadian the big five terdiri dari 44 item, peneliti membuang 2 item pertanyaan yang gugur dan memakai 42 item yang valid. Sedangkan pada skala overconfidence, tidak ada item yang dibuang sehingga memakai 5 item pertanyaan yang ada. Peneliti sengaja memakai item yang valid tanpa mengganti item yang gugur karena item-item yang valid tersebut dirasa sudah mewakili masing-masing indikator yang diukur.

\section{Uji Reliabilitas}

Suatu konstruk atau variabel dikatakan reliabel jika memberikan nilai Alpha Cronbach > 0,60 (Ghozali, 2007). Perhitungan reliabilitas menggunakan program SPSS 20 for windows. Hasil uji reliabilitas tipe kepribadian ditunjukkan dengan tabel berikut:

\begin{tabular}{cccc}
\hline \multicolumn{4}{c}{ Tabel 4 } \\
\hline No & Reliabilitas Skala Tipe Keperibadian Big Five \\
$\mathbf{1}$ & Aspek & Alpha Cronbach & Kategori \\
$\mathbf{2}$ & Agreeableness & 0.819 & Reliabel \\
$\mathbf{3}$ & Conscientiousness & 0.826 & Reliabel \\
$\mathbf{4}$ & Extraversion & 0.771 & Reliabel \\
$\mathbf{5}$ & Neuroticism & 0.731 & Reliabel \\
$\mathbf{6}$ & Openness & 0.808 & Reliabel \\
\hline
\end{tabular}

Dari tabel 4 diatas, maka dapat diketahui bahwa semua aspek tipe kepribadian (agreeableness, concientiousness, extraversion, neuroticism, openness) dan overconfidence dinyatakan reliabel.

\section{Uji Hipotesis}

\section{Analisis Uji Chi-Square}

Pengambilan keputusan uji chi-square yaitu berhubungan apabila nilai dari pearson chi-square $>$ dari tabel distribusi chi-square. Taraf signifikansi diperoleh jika level signifikan $<0.05$.

Hasil chi-square pada variabel faktor demografi adalah sebagai berikut: 
Tabel 5

Hasil Uji Chi Square

\begin{tabular}{c|c|c|c|c}
\hline & $\begin{array}{c}\text { Pearson Chi- } \\
\text { Square }\end{array}$ & Df & Sig & Keterangan \\
Jenis Kelamin & 18.121 & 1 & 0.000 & Hipotesis diterima \\
Usia & 9.995 & 2 & 0.007 & Hipotesis diterima \\
Pendidikan & 10.782 & 2 & 0.005 & Hipotesis diterima \\
\hline
\end{tabular}

\section{1.) Jenis Kelamin}

Nilai pearson chi - square dari jenis kelamin $10.480>3.841$ tabel distribusi chi-square dengan taraf signifikansi 0.000 kurang dari 0.05 yaitu yang berarti jenis kelamin mempunyai hubungan dengan overconfidence, sehingga hipotesis didukung. Hasil penelitian sesuai dengan penelitian Mishra (2015), Bashir et al (2013), Rekik \& Boujelbene (2013), Tecke (2011), Lin (2011), Kufepaksi (2010) dan Graham et al (2009) memperoleh hasil bahwa jenis kelamin mempunyai hubungan dengan bias overconfidence individu dalam pengambilan keputusan investasi dimana tingkat overconfidence laki-laki lebih tinggi dari pada wanita. Odean (2001) laki-laki lebih percaya diri dibandingkan wanita. Laki-laki melakukan trading berlebihan dan mencapai hasil yang lebih rendah daripada wanita.

\section{2.) Usia}

Pada variabel demografi yaitu usia, nilai pearson chi square $9.995>5.991$ tabel distribusi chi-square dengan nilai signifikansi 0.007 lebih kecil dari 0.05 yang berarti ada hubungan antara usia dengan bias overconfidence, maka hipotesis didukung. Hasil tersebut sesuai dengan penelitian yang dilakukan Onsomu (2015), Bashir et al (2013), Rekik \& Boujelbene (2013), Tekce (2011) dan Lin (2011) memperoleh hasil bahwa variabel demografi yaitu usia berhubungan dengan terjadinya overconfidence. Hal ini disebabkan karena semakin bertambahnya usia pengalaman hidup seseorang akan meningkat. Menkhoff et al (2006) Tingkat overconfidence meningkat seiring dengan pengalaman investor yang bertambah usia. Charli \& Eagly (1981) orang yang lebih tua memiliki pengalaman dan pengetahuan investasi yang cukup, dan mereka memiliki ide yang berbeda dari orang yang lebih muda dalam investasi.

\section{3.) Pendidikan}

Variabel pendidikan mempunyai nilai pearson chi - square $10.782>$ chisquare distribution table yaitu 3.841 menunjukkan bahwa ada hubungan yang signifikan antara pendidikan dengan overconfidence, hipotesis didukung. Hasil pengujian ini sesuai dengan penelitian Bhandari \& Dhaves (2006), Graham (2009), Jamshidinavid et al (2012), Bashir et al (2013), Mishra \& Mary (2015) dan Thomas dan Shinil (2015) menunjukkan bahwa variabel demografi yaitu pendikan mempunyai hubungan dengan terjadinya overconfidence pada investor. Hal tersebut karena semakin tinggi level pendidikan maka semakin tinggi tingkat overconfidence pada investor (Mishra, 2015). Tingkat pendidikan yang lebih tinggi menyiratkan bahwa orang memiliki pemahaman yang lebih baik dari masalah keuangan pribadi mereka, sehingga mereka akan lebih mampu untuk 
membuat keputusan keuangan dan memiliki kemampuan lebih untuk merencanakan masa depan.

\section{Analisis Regresi}

Analisis regresi untuk meneliti hubungan antara variabel independen (tipe kepribadian) dengan variabel dependen (overconfidence).

\begin{tabular}{|c|c|c|c|}
\hline \multicolumn{4}{|c|}{$\begin{array}{c}\text { Tabel 10 } \\
\text { Tabel Pengaruh Tipe Kepribadian dengan overconfidence }\end{array}$} \\
\hline \multirow[t]{2}{*}{ Variabel } & \multicolumn{2}{|c|}{ Overconfidence } & \multirow[t]{2}{*}{ Keterangan } \\
\hline & $\mathbf{t}$ & Sig & \\
\hline Agreeableness & 0.721 & 0.473 & $\begin{array}{l}\text { Hipotesis } \\
\text { ditolak }\end{array}$ \\
\hline Conscientiousness & 3.521 & 0.001 & $\begin{array}{l}\text { Hipotesis } \\
\text { diterima }\end{array}$ \\
\hline Extraversion & 2.062 & 0.042 & $\begin{array}{l}\text { Hipotesis } \\
\text { diterima }\end{array}$ \\
\hline Neuroticism & 0.665 & 0.508 & $\begin{array}{l}\text { Hipotesis } \\
\text { ditolak }\end{array}$ \\
\hline Openness & 2.062 & 0.042 & $\begin{array}{l}\text { Hipotesis } \\
\text { diterima }\end{array}$ \\
\hline
\end{tabular}

\section{4.) Agreeableness}

Variabel agreeableness (X4) secara statistik menunjukan hasil yang tidak signifikan, nilai signifikan kurang dari $\alpha(0.473<0,05)$ dan t hitung lebih kecil dari t tabel $(0.721<1.96)$. Sehingga variabel agreeableness tidak berpengaruh terhadap bias overconfidence yang berarti hipotesis tidak didukung. Hasil penelitian ini tidak sesuai dengan penelitian Zaidi \& Tauni (2012) dan Bashir et al (2013) terdapat hubungan antara tipe kepribadian agreableness dengan overconfidence. Tetapi sesuai dengan penelitian Schaefer et al (2004), Jamhidinavid et al (2012), dan Amiri et al (2013) bahwa tipe kepribadian agreeableness tidak berpengaruh terhadap overconfidence. Hal ini disebabkan karena individu agreeableness cenderung mematuhi saran dari orang lain (Robbins et al, 2008). Sedangkan investor overconfidence lebih percaya atas kemampuan yang dimilikinya (Odean, 1998).

\section{5.) Concientiousness}

Variabel concientiousness (X5) secara statistik menunjukan hasil yang signifikan pada nilai signifikan lebih besar dari $\alpha(0.001>0,05)$ dan $t$ hitung lebih besar dari t tabel (3.521>1.96). Sehingga variabel concientiousness berhubungan signifikan dengan bias overconfidence yang berarti hipotesis didukung. Hasil penelitian ini sesuai dengan penelitian Jamhidinavid (2012), Zaidi (2012) \& Bashir (2013) pada penelitiannya menyimpulkan bahwa tipe kepribadian conscientiousness berpengaruh terhadap overconfidence. Tipe kepribadian conscientiousness yang tinggi, percaya terhadap kemampuan yang dimilikinya. Hal tersebut disebabkan karena investor dengan tipe kepribadian concientiousness percaya bahwa performa mereka sendiri yang lebih baik dari investor lain dalam 
investasi (Schaefer et al, 2004). Dimana ciri investor overconfidence yaitu investor yang overestimate terhadap pengetahuan yang dimiliki oleh investor itu sendiri, dan underestimate terhadap prediksi yang dilakukan karena investor melebih-lebihkan kemampuan yang dimiliki sehingga cenderung meremehkan investor lain (Odean, 2001).

\section{6.) Extraversion}

Variabel extraversion (X6) secara statistik menunjukan hasil yang signifikan pada nilai signifikan lebih dari $\alpha(0.042>0,05)$ dan t hitung lebih besar dari t tabel (2.062>1.96). Sehingga variabel extraversion berpengaruh positif signifikan terhadap overconfidence yang berarti hipotesis didukung. Hasil penelitian ini sesuai dengan penelitian Amiri et al (2013), Bashir et al, Jamshidinavid (2012), Lin (2011), Schaefer et al (2004) yang menyimpulkan bahwa tipe kepribadian extroversion berpengaruh terhadap overconfidence. Hal tersebut disebabkan karena investor overconfidence akan mengambil risiko tinggi untuk memperoleh keuntungan, sementara investor yang rasional berusaha untuk memaksimalkan keuntungan dengan cara memperkecil jumlah dari risiko yang diambil (Nofsinger, 2005). Extraversion berhubungan dengan overconfidence (Pallier et al, 2002), extraversion berhubungan dengan narsisme (Paulhus \& Williams, 2002) dan narsisme berkorelasi dengan overconfidence.

\section{7.) Neuroticism}

Variabel neuroticism (X7) secara statistik menunjukan hasil yang tidak signifikan pada nilai signifikan lebih dari $\alpha(0.508>0,05)$ dan $t$ hitung lebih kecil dari $\mathrm{t}$ tabel $(0.065<1.96)$. Sehingga variabel neuroticism tidak berpengaruh terhadap overconfidence yang berarti hipotesis tidak didukung. Hasil penelitian ini tidak sesuai dengan peneltian Zaidi \& Tauni (2012) dan Lin (2011) dimana neuroticism mempunyai hubungan negatif dengan overconfidence. Tetapi, hasil dari penelitian sesuai penelitian yang dilakukan Schaefer et al (2004), Jamshidinavid (2012), Amiri et al (2012) dan Bashir et al (2013) yang menghasilkan bahwa tipe kepribadian neuroticism tidak berhubungan dengan terjadinya bias overconfidence pada mahasiswa. Hal tersebut disebabkan karena investor neurotisme menggambarkan seseorang yang memiliki emosi negatif, seperti rasa khawatir dan rasa tidak aman. Depresi berkaitan dengan underconfidence (Stone et al, 2001). Jhonshon et al (2001) investor tidak overconfidence ketika memiliki sifat cemas. Investor yang memiliki sifat neuroticism menjual saham mengikuti saran dari investor profesional dan tidak percaya diri dengan kemampuan yang dimiliki.

\section{8.) Openness}

Variabel openness (X8) secara statistik menunjukan hasil yang signifikan pada nilai signifikan kurang dari $\alpha(0.472<0,05)$ dan $t$ hitung lebih besar dari $t$ tabel (2.062>1.96). Sehingga variabel openness berpengaruh terhadap overconfidence yang berarti hipotesis diterima. Hasil ini sesuai dengan penelitian yang dilakukan Lin (2011), (Jamshidinavid, 2012), Bashir et al (2013) \& Amiri (2013) tipe kepribadian openness pada investor berhubungan dengan bias overconfidence. Hal tersebut disebabkan karena tipe kepribadian openness, merupakan seseorang yang tertarik terhadap hal-hal baru (Robbins et al, 2008). Penelitian mengenai investasi menyatakan mereka memiliki kemampuan yang 
lebih dibandingkan dengan yang lain, dan tipe seperti ini cenderung senang dengan keuntungan yang tinggi (Peterson, 2011). Schaefer et al (2004) tipe kepribadian openness mempunyai rasa ingin tahu, sehingga mereka sering membeli dan menjual saham karena overconfidence. Barber \& Odean (1999) menemukan, investor dengan sifat openness merupakan individu yang tertarik dengan hal-hal baru dan pengalaman baru, berorientasi pada tindakan, dan ingin tahu tentang ide orang lain membeli dan menjual saham mereka karena overconfidence.

\section{KESIMPULAN DAN SARAN}

Berdasarkan hasil analisis dan pembahasan, dapat disimpulkan bahwa faktor demografi (jenis kelamin, usia dan pendidikan) berpengaruh positif signifikan terhadap overconfidence. Hasil analisis regresi menunjukkan bahwa terdapat pengaruh positif signifikan variabel tipe kepribadian concientiousness, extroversion dan openness terhadap overconfidence, sedangkan agreeableness dan neuroticism tidak berpengaruh terhadap overconfidence.

Pada penelitian selanjutnya diharapkan peneliti lain memilih responden selain mahasiswa dan memilih responden yang telah mempunyai pengalaman investasi yang cukup. Selain itu juga diharapkan untuk menambah variabel dependen yaitu bias perilaku keuangan lain dan variabel independen pada faktor demografi dan mencari faktor lain yang kira-kira berhubungan dengan terjadinya bias perilaku keuangan. 


\section{DAFTAR PUSTAKA}

Amiri, Shahla, Nooredin R \& Gholam H. V. (2013), The effect of the interaction between demographic factors and personality traits and Financial Behaviour Factors in Terms of Investment Decision Making. Journal Appl. Sci. \& Agric., 8(5): 721-728.

Bashir, Dr., T et al (2013), Impact of Demographics and Personality traits on Confidence level: Determinants of Overconfidence (Evidence from employees and students) : Journal of Business and Management. Volume 10, Issue 1 (May. - Jun. 2013), PP 58-67.

Bashir, Dr. T et al (2013), Are Behavioral Biases Influenced By Demographic Characteristics \& Personality Traits? Evidence From Pakistan : Journal of Business and Management. European Scientific Journal. October 2013, edition vol.9, No.29.

Barber, B., Odean, T (2000), Trading is Hazardous to Your Wealth: the Common Stock Performance of Individual Investors. Journal of Finance. 55, $773-806$.

Barber, Brad M., and Terrance Odean (2001), Boys Will Be Boys: Gender, Overconfidence, and Common stock Investment, Quarterly Journal of Economics 116, 261-292.

Barberis, N. And R.H. Thaler . 2003. A Survey of Behavioral Finance. Handbook of the Economic of Finance. Elsevier : Amsterdam.

Bhandari and Deaves (2006), The Demographics of Overconfidence. Jurnal of Behavioral Finance, Vol 7, No 1.

Charli, L. L. and A. H. Eagly, "Sex of researchers and sex-typed communications as determinants of sex differences in influence ability: a Meta-Analysis of Social Influence Studies," Psychol. Bull., vol. 90, no. 1, pp.1-20, 1981.

DeBondt, W.F.M. and Thaler, R. 1985. Does The Stock Market Overreact?, Journal of Finance. 40 (3) : 793-805.

Geffert. \& Christensen. (1998), Things they carry: Attitudes toward, opinions about, and knowledge of libraries and research among incoming college students.

Felton, James., Gibson, Bryan., and David M Sanbonmatsu., (2003), Preference for Risk in Investing as a Function of Trait Optimism and Gender. Journal of BehavioralFinance $\mathrm{Vol}$ 4, no 1, 33-40. 
Ferguson, E., Heckman, J., Corr, P. (2011), Personality and Economics: Overview and Proposed Framework,Personality and Individual Differences, No. 5151, pp. 201.

Ghozali, Imam. 2007. Aplikasi Analisis Multivariate Dengan Program SPSS. BPUniversitas Diponogoro: Semarang.

Graham, J. R., Harvey, C.R., and Huang, H. (2009), Investor Competence, Trading Frequency and Home Bias, 55(7), 1094-1106.

Hogarth, J.M. (2002), Financial Literacy and Family and Consumer Sciences, Journal of Family and Consumer Sciences, Vol. 94, No 1, pp.15-28.

Jamshidinavid et al. (2012), The Impact of Demographic and Psychological Characteristics on the Investment Prejudices in Tehran Stock. European Journal of Business and Social Sciences, Vol. 1, No. 5, pp 41-53, August 2012.

Kufepaksi, Mahatma., (2010) .Investor Overconfident Dalam Penilaian Saham :Perspektif Gender Dalam Eksperimen Pasar. Volume 14, No.2, Th. 2010: Hal. 131-150.

Korniotis, G. M. and A. Kumar, (2011) Do older investors make better investment decisions?" Review of Economics and Statistics, 93 (1), pp. 244-265.

Lemeshow, S. \& David W.H.Jr. 1997. Besar Sampel Dalam Penelitian Kesehatan. Gadjah Mada University Press, Yogyakarta.

Lewellen, Wilbur., G, Ronald., C, Lease., Gary G Schlarbaum (1977), Patterns of Investment Strategy and Behavior Among Individual Investors. Journal of Business, 296-333.

Lin, H. (2011), Elucidating the Influence of Demographics and Psychological Traits on Investment Biases, World Academy of Science, Engineering and Technology.

Mayfield, C., Perdue, G dan K. Wooten. (2008). Investment Management and Personality Type. Financial Services Review vol 17.

McCrae, R.R \& Costa Jr., P.T. 1997. Personality Trait Structure as a Human Universality. Americant Psychologist. Vol 52. No 5. 509-516.

McCrae, R.R \& Costa Jr., P.T. 2008. Revised NEO Personality Inventory and NEO Five-Factor Inventory: Professional Manual. FL: Assessment Resources. 
Menkhoff, L., U. Schmidt and T. Brozynski 2006. The Impact of Experience on Risk Taking, Overconfidence and Herding of Fund Managers: Complementary Survey Evidence, European Economic Review, 50, pp. 1753-1766.

Mishra, K.C. \& Mary J. Metilda (2015), A study on the impact of investment experience, gender, and level of education on overconfidence and selfattribution bias : IIMB Management Review (2015) 27, 228-239.

Muhammad, Djibril. 2013. Minat Mahasiswa Yogyakarta jadi Investor Tinggi. https://www.republika.co.id/berita/nasional/jawa-tengah-diynasional/13/11/15/mwaiwf-minat-mahasiswa-yogyakarta-jadi-investortinggi.

Nofsinger, John R. 2005. Psychology of Investing. Second Edition. New Jersey. Precentice-Hall Inc.

Odean, Terrance (1998), Volume, Volatility, Price, and Profit When All Traders are Above Average, Journal of Finance, LIII, December, 1887 -1934.

Onsomu, Zipporah Nyaboke (2015), Effect of Age on Investor Decisions. International Journal Of Innovative Research \& Development, ISSN $2278-0211$.

Pallier, G., Wilkinson, R., Danthir, V., Kleitman, S., Knezevic, G., Stankov, L., \& Roberts, R. D. (2002). The role of individual differences in the accuracy of confidence judgments. Journal of General Psychology, 129, 257-299.

Paulhus, D. L., \& Williams, K. M. (2002). The Dark Triad of personality: Narcissism, Machiavellianism and psychopathy. Journal of Research in Personality, 36, 556-563.

Peterson, Richard. (2011), The Personality Traits of Successful Investor's Personality and Perceptual Biases Effect on Financial Decisions. Internastional Jurnal of Economics and Finance.

Pompian, Michael M. 2006. Behavioral Finance and Wealth Management. John Wiley \& Sons Inc. New Jersey.

Rekik, Yosra Mefteh. Younes Boujelbene. Determinants of Individual Investors' Behaviors: Evidence from Tunisian Stock Market. Journal of Business and Management. (IOSR-JBM). e-ISSN: 2278-487X. Volume 8, Issue 2 (Jan. - Feb. 2013), PP 109-119.

Robbins, Stephen. P, Judge, Timothy. A, (2008), Organizational Behavior, Prentise Hall, 100-110. 
Robbins, Stephen P. 2001. Perilaku Organisasi. Edisi 8. Prentice Hall, Jakarta.

Rothmann, S; E.P. Coetzer., (2013), The big five personality dimensions and job performance. SA Journal of Industrial Psychology 29.

Schaefer, P. S. et al (2004) Overconfidence and the Big Five,J. Res. Pers, 38,473480.

Sembel, R. \& Trinugroho, I. (July 2011), Overconfidence and Excessive Trading Behavior, Journal of Business and Management, Vol. 6, No. 7.

Shefrin, \& Hersh (2007), Behavioral Corporate Finance. Decisions that Create Value. McGraw-Hill/Irwin. New York.

Sugiama, Gima.A. 2012. Metode Riset Bisnis dan Manajemen. CV Gurdaya Inti Marta Bandung.

Stone, E. R., Dodrill, C. L., \& Johnson, N. (2001). Depressive cognition: A test of depressive realism versus negativity using general knowledge questions. Journal of Personality, 135, 583-602.

Tekçe, Bülent (2011), What Factors Affect Behavioral Biases?: Evidence From Turkish Individual Stock Investors.

Thomas, Sam \& Shinil Sebastian (2015), Analysis Of Changes In Overconfidence Bais Of Stock Market Traders In Indian Stock Market. Journal of Business and General Management, Vol. 4, Issue 6, Oct - Nov 2015, 4956.

Williams, D. G. (1992). Dispositional optimism, neuroticism, and extraversion. Personality and Individual Differences, 13, 475-477.

Zaidi, Farheen Btool \& Muhammad Zubair Tauni (2012), "Influence of Investor's Personality Traits and Demographics on Overconfidence Bias" : Journal Of Contemporary Research, IN BUSINESS. VOL 4, NO 